III!!1! 総説

\author{
ビタミンン $\mathrm{E}$ \\ 五十嵐脩 \\ お茶の水女子大学 \\ Vitamin E Recent Topics \\ Osamu Igarashi \\ Ochanomizu University
}

ビタミン E は脂溶性ビタミンの 1 つで, 栄養所要量の面から考えると, 成人 1 人当たり $10 \mathrm{mg} /$ 日前後とされ,

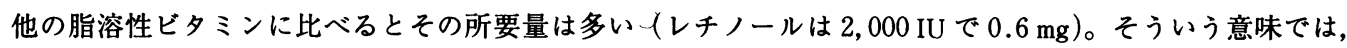
ビタミンCなどと同じく調節因子として作用している点が大きいと考えられる。

さて, ビタミン $\mathrm{E}$ は最初抗不妊因子として，レタスなどの野菜に存在することが見出されてから 50 年以上 が経過した。その間, ビタミン $\mathrm{E}$ の同族体としてトコフェロール, トコトリエノール各 4 種ずつ計 8 種が自 然界に存在することが見出された。その構造式は図 1 に示すとおりで, いずれもクロマン環の 6 位に水酸基を もつ一種のフェノールである。また，側鎖については，フィトール由来のトコフェロールと側鎖に二重結合の あるトコトリエノールが存在する。天然のトコフェロールは側鎖についてはいずれも R 配位で, トコトリエ ノールは、 $2 \mathrm{R}, 3^{\prime}, 7^{\prime}$-トランス型の結合となっている。

\title{
I. ビタミンEの抗酸化活性
}

食品あるいは生体内で起こる過酸化反応は, (1) フリーラジカル反応 (自動酸化), (2) 一重項酸素の付加反 応に大別される。前者の反応はよく知られているように, 中間体としてのペルオキシラジカルの生成と,ペル オキシラジカルによる多価不飽和脂肪酸への攻撃を含むものである。後者の反応では，一重項酸素 $\left({ }^{1} \mathrm{O}_{2}\right)$ は

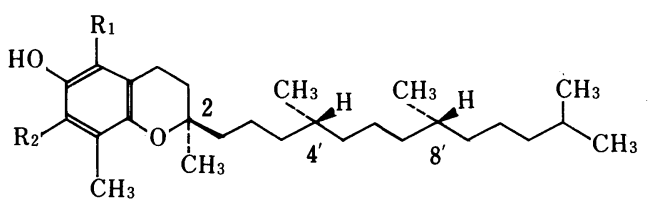

$\alpha-ト コ フ ェ ロ ー ル *(\alpha-T)$<smiles>[R]c1c(C)c2c(c([R])c1O)CCC(C)(CC/C=C(/C)CC/C=C(\C)CCC=C(C)C)O2</smiles>

トコトリエノール** $(\mathrm{T}-3)$

$$
\begin{aligned}
& \mathrm{R}_{1} \quad \mathrm{R}_{2} \\
& \alpha \text {-トコフェロール } \mathrm{CH}_{3} \quad \mathrm{CH}_{3} \quad \alpha \text {-トコトリエノール } \\
& \beta \text {-トコフェロール } \mathrm{CH}_{3} \quad \mathrm{H} \quad \beta \text {-トコトリエノール } \\
& \text { rートコフェロール } \quad \mathrm{H} \quad \mathrm{CH}_{3} \quad r \text { トコトリエノール } \\
& \text { ઈートコフェロール } \quad \mathrm{H} \quad \mathrm{H} \quad \delta \text {-トコトリエノール }
\end{aligned}
$$

図 1 ビタミン $\mathrm{E}$ 同族体の構造

* 天然型は $\mathrm{d}$ 型 $\left(2 \mathrm{R}, 4^{\prime} \mathrm{R}, 8^{\prime} \mathrm{R}\right)$ で, $\alpha \sim \delta$ が存在。RRR-T ともいう。合成品は $\mathrm{dl}$ 型（2 RS, $\left.4^{\prime} \mathrm{RS}, 8^{\prime} \mathrm{RS}\right)$ で, $\mathrm{dl}-\alpha-\mathrm{T}$ のみが市販されている。

** 天然型は $2 \mathrm{R}, 3^{\prime}, 7^{\prime}$-all trans で $\alpha \sim \delta$ が存在するが, 生体成分としての含量はトコフェロールに比べ 極めて低い。 
二重結合への付加性が極めて大きいため, 容易に二重結合に付加し，ヒドロペルオキシドを生成する。

この両者の反応の相違点は, 前者が連鎖反応であるのに対し, 後者が単発反応であるという点である*。し

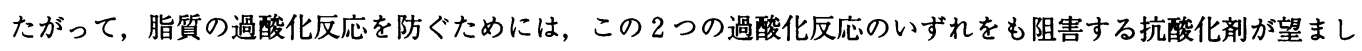
いことになる。従来, ともすれば, 食品に用いた際, ビタミン $\mathrm{E}$ は抗酸化剤としての持続性に欠け, 抗酸化 力が弱いとされ, 特に $\alpha$-トコフェロールでこの傾向が著しいとされてきた。そして, 合成の抗酸化剤のほう が抗酸化力の点からは強いと指摘されてきた1)。

\section{1. 自動酸化の阻害}

近年の研究で, Ingold $ら^{2)}$, 二木ら ${ }^{3)}$, Packer $ら^{4)}$, Simic $^{5)}$ はいずれも, フリーラジカル反応中に生成される 中間体であるペルオキシラジカルなどの酸素ラジカルと, 各種の抗酸化剤， $\alpha$-トコフェロールをはじめとす るトコフェロール類との反応性に注目して研究を進め, それらと各種抗酸化刘との反応速度定数（実際は自動 酸化の阻害をするので, 阻害定数ともいわれる）を求めた。

これらの研究によれば, 表 1 に示すように, ペルオキシラジカルとの反応性は $\alpha$ ートコフェロールが最も優 れ，次いで $\gamma$-トコフェロールであり，BHA，BHT などの合成抗酸化剂は極めて悪いことがわかる。なお， PMHC は $\alpha$-トコフェロールの側鎖のないモデル化合物で， $\alpha$-トコフェロールと同等の活性を示す。

このことは, 食品, あるいは生体系から過酸化反応を開始する酸素ラジカルであるペルオキシラジカルを速 やかに除去する能力においては， $\alpha$ ートコフェロールが極めて優れていることを示すとともに，生体内で最も 生理活性が高いビタミン Eとして $\alpha$ ートコフェロールがその地位を占めていることは自然界の合目的的淘汰と も考えられる(表 2 )。

このような結果と従来のトコ フェロールについての抗酸化剤と しての評価をどのように考えれば よいであろうか。

現在までの知見によれば，次の ようにまとめることができる。

すなわち， $\alpha$ ートコフェロール はペルオキシラジカルとの反応性 に優れているため, 図 2 に示すよ うに分解性が大きい6,7)。このこ とを模式的に考えると， $\alpha$-トコ フェロールは反応性が高いために 残存している間はヒドロペルオキ シドの集積はもたらさないが, そ の分解は速やかに進行する。これ に対し， $\gamma$ ートコフェロール, 合

表 1 抗酸化剂のペルオキシラジカルとの反応性 ${ }^{2)}$

\begin{tabular}{lc}
\hline \multicolumn{1}{c}{ Antioxidant } & $10^{-4} k_{5}{ }^{* \mathrm{a}}$ \\
\hline$\alpha$-tocopherol & $235 \pm 50$ \\
$\beta$-tocopherol & $166 \pm 33$ \\
$\gamma$-tocopherol & $159 \pm 42$ \\
$\delta$-tocopherol & $65 \pm 13$ \\
$2,2,5,7,8$-pentamethyl-6-hydroxychroman (PMHC) & $214 \pm 81$ \\
2, 3, 5, 6-tetramethyl-4-methoxyphenol (TMMP) & $21 \pm 2^{* \mathrm{~b}}$ \\
pentamethylphenol & $14 \pm 1^{* \mathrm{~b}}$ \\
$2,3,5,6$-tetramethylphenol & $5.6 \pm 0.0_{1}^{* \mathrm{~b}}$ \\
2,6 -di-tert-butyl-4-methoxyphenol(BHA) & $7.8 \pm 0.2_{2}^{* \mathrm{~b}}$ \\
2,6 -di-tert-butyl-4-methylphenol (BHT) & $1.2 \pm 0.0_{2}{ }^{* \mathrm{~b}}$ \\
1-naphthol & $24 \pm 3$ \\
1-hydroxypyrene & $186 \pm 70$ \\
$N, N^{\prime}$-diphenyl-p-phenylenediamine & $117 \pm 42$ \\
\hline
\end{tabular}

$k_{5} \times 10^{-4}$ はペルオキシラジカルとの反応性を示し，大きいほうが速や かにペルオキシラジカルを消去することを示している。

*a, 数值は平均土標準偏差値 $\left(\right.$ 単位 $\left.: \mathrm{M}^{-1} \mathrm{~s}^{-1}\right)$ 。

*b，2 者の測定による平均値。

* ただし, 生成したヒドロペルオキシドが開裂してラジカルを生成すると, フリーラジカル反応を誘発す ることになる。 
成抗酸化剂ではその反応性が遅いために，分解率は低く，長期間にわたり，残存する。したがって，ヒドロぺ ルオキシドは徐々に蓄積されるが，食品として考えた場合，毒性をもたらすほどの量ではなく，しかも長期間 にわたり残存するため効果が長続きすることになる（図 2 )。

表 2 過酸化脂肪の生成と抗酸化剂による阻害

\begin{tabular}{ll}
\hline 自動酸化のフリーラジカル連鎖反応 & $\left\{\begin{array}{l}\mathrm{ROO} \cdot+\mathrm{RH} \\
\mathrm{R} \cdot+\mathrm{O}_{2}\end{array} \mathrm{ROO} \cdot\right.$ \\
抗酸化剂による連鎖阻害反応 & $\mathrm{ROO} \cdot+\mathrm{AH}_{2} \longrightarrow \mathrm{ROOH}+\mathrm{AH} \cdot$ \\
抗 酸 化 剂 $の$ 再 生 機 構 & $\left\{\begin{array}{l}\mathrm{AH} \cdot+\mathrm{AH} \cdot \longrightarrow \mathrm{AH}_{2}+\mathrm{A} \\
\mathrm{AH} \cdot+\mathrm{BH}_{2} \longrightarrow \mathrm{AH}_{2}+\mathrm{BH} \cdot \\
\mathrm{AH} \cdot+\mathrm{BH} \cdot \longrightarrow \mathrm{AH}_{2}+\mathrm{B}\end{array}\right.$ \\
\hline
\end{tabular}

注) $\mathrm{RH}$, 脂肪酸; $\mathrm{ROO}$, ペルオキシラジカル； $\mathrm{AH}_{2}$, 抗酸化剤 ; $\mathrm{BH}_{2}$, エネルギスト。

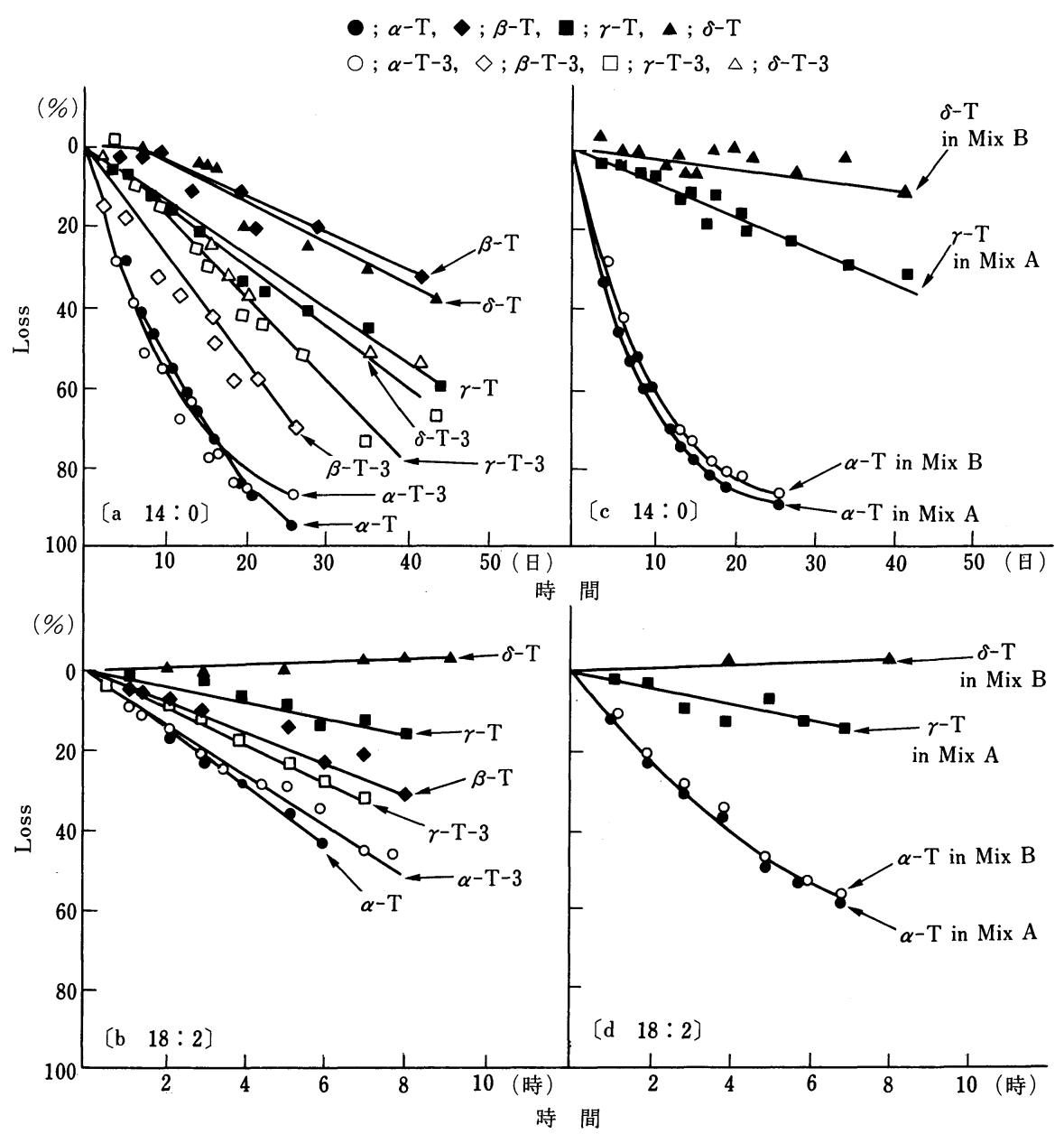

図 2 自動酸化中のトコフェロール局族体の分解率 ${ }^{7)}$

$\mathrm{a}, \mathrm{c}$ はミリスチン酸メチル中。b, d はリノール酸メチル中。Mix $\mathrm{A}=\alpha-\mathrm{T}+\gamma-\mathrm{T}, \mathrm{Mix} \mathrm{B}=\alpha-\mathrm{T}+\delta-\mathrm{T}$ 。 
つまり，食品の場合には，反応性が速いことよりは，効果が長続きし，かつ適度の反応性を示すもののほう が抗酸化剂使用の目的に適っているといえよう。

これに対し, 生体系にあっては, 反応性にポイントがあるために, 優れた抗酸化剂である $\alpha$ トコフェロー ルが最高の生理活性を有している。

\section{2. 一重項酸素との反応性}

一重項酸素 $\left({ }^{1} \mathrm{O}_{2}\right)$ は，我々が呼吸している酸素に比べ，エネルギー的に非常に活性化された状態にある酸 素である。これに対し通常の酸素は三重項酸素 $\left({ }^{3} \mathrm{O}_{2}\right)$ といわれ，最も安定である。

このようにエネルギー的に活性化されているので, 一重項酸素は二重結合に容易に付加する（ ${ }^{3} \mathrm{O}_{2}$ は付加で きない)。したがって, この ${ }^{1} \mathrm{O}_{2}$ を除去するためには, 速やかに ${ }^{1} \mathrm{O}_{2}$ と反応する抗酸化剂が最も望ましいことに なる。

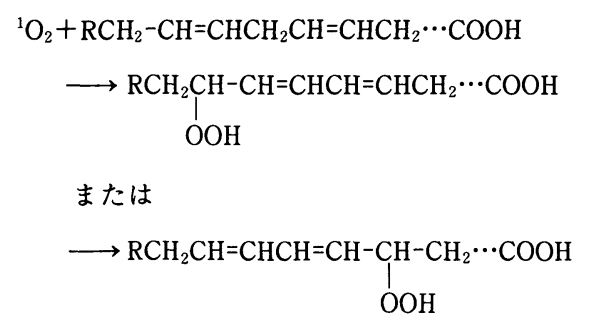

植物も含めて ${ }^{1} \mathrm{O}_{2}$ との反応性が最も高いのは, $\beta$-カロチンをはじめとするカロチノイド色素であり, 次い でトコフェロール類である。トコフェロールの中でもこの反応性は $\alpha$-トコフェロールが最も高い。しかし， カロチノイド色素に比べると $1 / 100$ のオーダーになる ${ }^{8,9)}$ 。カロチノイド色素の能力が大きいのは, 光合成に 際し，葉緑体内で ${ }^{1} \mathrm{O}_{2}$ が生成するためであろう。

動物体内でも ${ }^{1} \mathrm{O}_{2}$ が生成する反応が知られ，光過敏症の際の皮虐のかぶれ，湿疹は ${ }^{1} \mathrm{O}_{2}$ による脂質過酸化反 応によるものと考えられていて ${ }^{10)}$, 治療には $\alpha$-トコフェロールが投与されている。

以上述べたように， $\alpha$-トコフェロールはビタミン $\mathrm{E}$ 同族体中最も有効な抗酸化剤として，フリーラジカル 反応の停止, ${ }^{1} \mathrm{O}_{2}$ の除去という 2 つの機能を果たしている。

このような $\alpha$-トコフェロールの作用部位は, リノール酸, アラキドン酸などの多価不飽和脂肪酸 (PUFA) の含量の高いリン脂質が主成分である生体膜であり, 生体膜での脂質の過酸化反応の抑止に作用している。

\section{II. ビタミン $E$ の組織内濃度と食餌因子}

ビタミン $\mathrm{E}$ は脂溶性ビタミンであるため, 脂肪と同じく, リンパ系を介して吸収される。そして血液中で はリポたん白質で運搬され, 各組織に移行していく11)。また, 細胞内の取り込みにはLDLと HDL 中のトコフェ ロールが移行されると考えられているが, LDL 中のトコフェロールは LDL-コレステロールと同じく, LDLレセプターを介するものと考えられている ${ }^{12)}$ 。しかし，LDL-レセプター欠損，あるいは量的に少ない線維芽 細胞でもその移行量は低下するにしても取り込まれることから，LDL と同時にHDLからも移行するものとい

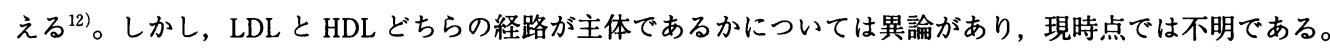

さて，このように組織に移行される $\alpha$-トコフェロールの組織内濃度には食餌因子が影響することはよく知 られている。ここではこうした食慨因子のいくつかについて述べる。 


\section{1. 食飳脂肪の不飽和度}

古くからの研究で, 食餌中の脂肪の不飽和度を上昇させるとビタミン $\mathrm{E}$ 欠乏が早期に発現することが知ら れている ${ }^{13)}$ 。こここは, ビタミン E の栄養所要量を考える際の PUFA と E との摂取量比 $(\mathrm{E} / \mathrm{PUFA} \times 1,000)$ をいくつ以上にするべきかという考え方に現れている。

鄭らは食餌脂肪の種類を変えた時の肝臓中の $\alpha$-トコフェロールの濃度を測定し, 油脂中のリノール酸含量 の大きい油脂のほうが $\alpha$-トコフェロールがやや低く，イワシ油などの魚油では低いことを見出している14)。 毛利らは魚油とコーン油を混合した際, 魚油投与の影響の出方がイワシ油とタラ肝油（CLO）で異なり，イワ シ油のほうが影響の出方が大きいことを見出した。そして，魚油投与により，肝臓および赤血球，血清のビ夕 ミン $\mathrm{E}$ 值が著しく低下することを見出し，これは $\mathrm{EPA}, \mathrm{DHA}$ *などの含量の高い魚油を与えたため, ビタミ ン E の消費が立進するとともに, 臓器での貯留性が低下したためと推定している ${ }^{15)}$ (表 3 )。このほか, 佐野 らは, 肝臓以外の臓器でも同様の現象が起こることを推定している ${ }^{16)} 。$

\section{2. たん白買の影筍}

また，筆者ら ${ }^{17,18)}$ は，ビタミン $\mathrm{E}$ の臓器濃度とたん白質摂取レベル，たん白質の種類の違いなどの影響など について検討し，たん白質レベルを $10 \% ， 20 \% ， 40 \%$ ガインとすると， $\alpha$-トコフェロール投与量 $70 \mathrm{mg}$ の 場合, $10 \%$ カゼイン群で各蔵器（肝・腎・脾・心・肺）での $\alpha$-トコフェロール濃度が低下すること, $20 \%$ と 40\%では差が少ないことなどを見出した。また，ビタミン E 欠そ食を与えた際には，40\%カゼイン群のほう

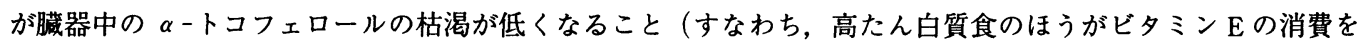
節約する), ビタミン E 欠乏からの回復でも同様に40\%の高たん白質群のほうが回復が速やかなことなどを見 出した。この実験においては, カゼインと大豆たん白質を比較すると, 大豆たん白質でビタミン $\mathrm{E} の$ 臓器濃 度が低くなることが見出された。

\section{3. ビタミン C との相互作用}

油脂の自動酸化に際しては，トコフェロールの抗酸化作用に対し，アスコルビン酸（AsA）が相乗的に作用 することはよく知られており, その際, トコフェロールの酸化で生じたトコフェロールラジカルの還元に AsA が水素供与体として作用している ${ }^{19,20)}$ 。このような反応が生体でも起こり得るか否かについてははっきり

表 3 タラ肝油の㠌取レベルと肝臓ビタミン $\mathrm{E}$

\begin{tabular}{lccc}
\hline & \multicolumn{2}{c}{$\begin{array}{c}\text { Serum } \\
\alpha\end{array}$} & \multicolumn{2}{c}{ Liver } \\
\cline { 3 - 4 }$(\mu \mathrm{g} / \mathrm{dl})$ & $274.6 \pm 35.2(100 \%)$ & $16.4 \pm 1.6(100 \%)$ & $\begin{array}{c}\text { TBA value } \\
(\mathrm{MDA} \mathrm{nmol} / \mathrm{g})\end{array}$ \\
\hline $100 \%$ Corn & $223.5 \pm 50.9(81.4)$ & $15.1 \pm 1.2(92.1)$ & $73.3 \pm 19.2(100 \%)$ \\
$25 \%$ CLO & $154.1 \pm 17.5(56.1)^{* \mathrm{a}}$ & $11.0 \pm 1.3(67.1)^{* \mathrm{a}}$ & $216.2 \pm 53.1(295)^{* \mathrm{a}}$ \\
$50 \%$ CLO & $144.9 \pm 12.2(52.7)^{* \mathrm{a}}$ & $10.5 \pm 1.0(64.0)^{* \mathrm{a}}$ & $379.8 \pm 64.4(518)^{* \mathrm{~b}}$ \\
$70 \%$ CLO & $143.6 \pm 14.0(52.3)^{* \mathrm{a}}$ & $8.6 \pm 1.0(52.4)^{* \mathrm{a}}$ & $390.2 \pm 92.4(532)^{* \mathrm{~b}}$ \\
$100 \%$ CLO+V.E & $26.7 \pm 8.9(9.7)^{* \mathrm{~b}}$ & $1.9 \pm 0.4(11.5)^{* \mathrm{~b}}$ & $436.7 \pm 96.6(596)^{* \mathrm{~b}}$ \\
\hline $100 \%$ CLO-V.E & &
\end{tabular}

数値は 6 ～検体による平均土標準偏差値。（）内の数值は $100 \%$ Corn 群に対する割合。

*a, b $100 \%$ Corn 群に対して, 各々 $p<0.01, p<0.001 て ゙$ 有意差のあることを示す。

* EPA，エイコサペンタエン酸； DHA，ドコサヘキサエン酸。 
した実験的証明は得られていない。しかし，AsA を大量投与するとラットでは脂質の過酸化反応が促進され， 溶血率が促進されること ${ }^{21)}$, 酵素活性への関連性 ${ }^{22,23)}$ な゙から何らかの相互作用をもつものと考えられている。 筆者らはこの点について実験を行い， $\alpha$-トコフェロールのある投与レベルにおいては, AsA の投与量との間 に一定の関係があり，AsAの投与量を増やすと蔵器中の $\alpha$-トコフェロール量が低下していく現象をモルモッ トで観察している ${ }^{22)}$ 。しかし，このような $\alpha$-トコフェロールとAsA の生体内での相互作用については今後の 解明が必要であろう。

\section{III. 健康とビタミン $\mathrm{E}$ 摄取}

最近, 発表された Gey らのデータは 6 年間の抗酸化作用を有する栄養素（ビタミン A, C, E, $\beta$-カロチン, セレン）の摂取レベル, 血中濃度と, 虚血性心疾患, 腸ガンの罹患率との相互関係を調ベている ${ }^{23)}$ この関係 を虚血性心疾患について示したのが図 3 である。腸ガンについても同様な関係が見出されており，表 4 に示す ようなビタミンの摂取レベルがこうした疾患の予防に望ましいとされている23)。

こうした疾病の予防とビタミン $\mathrm{E}$ の摂取量との関係については, 薬理量的レベルでのビタミン $\mathrm{E}$ 摂取の効 果については数多くの報告があるが, 疾病の予防という視点ではっきりとした有意義な報告は数少ない。ガン についても, 従来の血清のビタミン $\mathrm{E}$ 濃度との関係では有意義な報告はほとんどない。したがって，このよ うにはっきりしたデータが公表されたことは意義深いといえよう。

\section{IV. ビタミンE はエステル型と遊離型でどちらの効果が大きいか}

ビタミン E はエステル型のものも吸収時に小腸壁で加水分解されるため, 遊離型のものと同様な効果をも

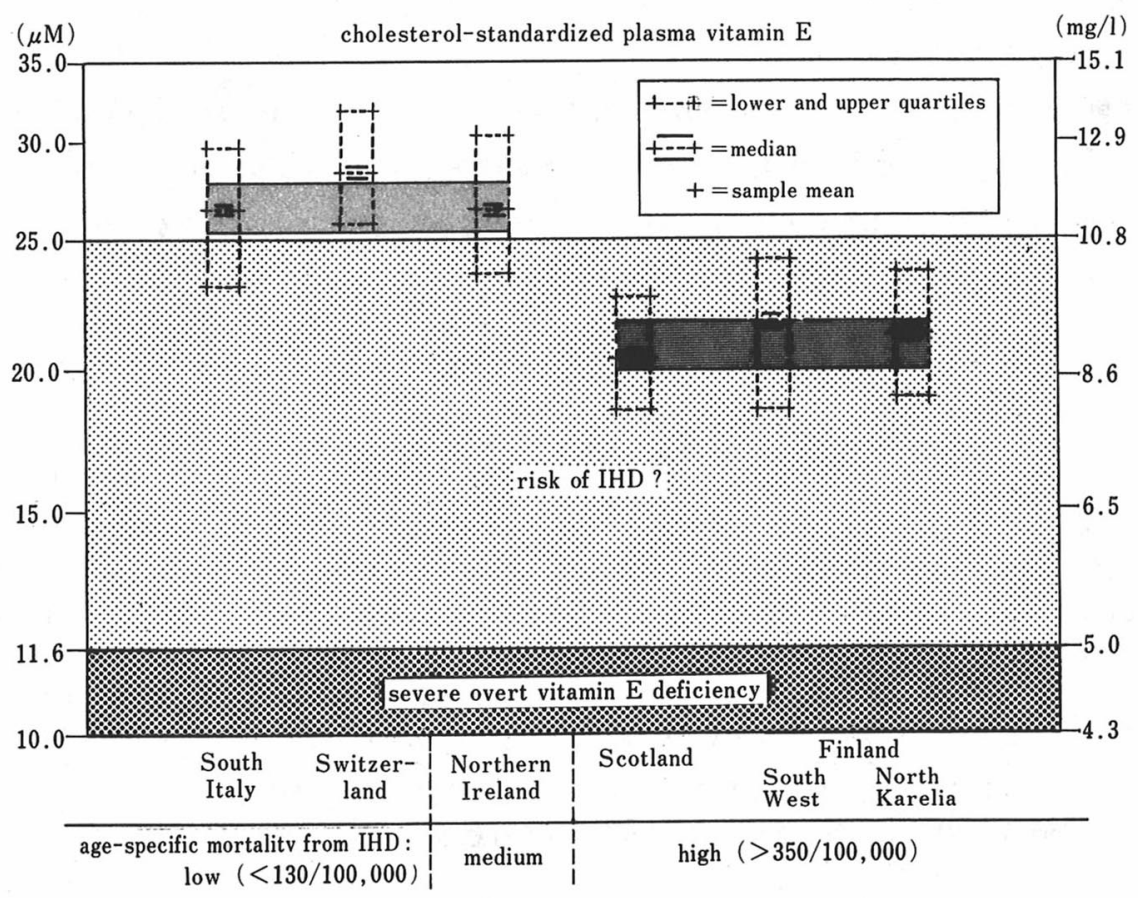

図 3 コレステロール，ビタミン E 值からみた国別の虚血性心疾患(IHD)の危険性(40４9歳の健康な男性) 
表 4 疾患予防のためのビタミン E と, 血槳値の関係と非喫煙中年男性におけるその攝取レベル

\begin{tabular}{llcc}
\hline Antioxidant & \multicolumn{1}{c}{ Health hazard } & $\begin{array}{c}\text { Desirable plasma } \\
\text { level }(\mu \mathrm{M})\end{array}$ & $\begin{array}{c}\text { Prudent daily intake for } \\
\text { optimum health } \\
\text { male nonsmokers) }\end{array}$ \\
\hline$\beta$-Carotene & $\begin{array}{l}\text { Lung cancer } \\
\text { Lung diseases } \\
\text { Stomach cancer }\end{array}$ & $>0.4$ & $\begin{array}{l}15 \mathrm{mg} \text { (minimum in NCI- } \\
\text { sponsored intervention } \\
\text { trials) }\end{array}$ \\
\hline Vitamin A & Stomach cancer & $>2.1$ & $\begin{array}{c}1 \mathrm{mg} \\
\text { Vitamin C }\end{array}$ \\
\hline $\begin{array}{l}\text { Standardized } \\
\text { vitamin E }\end{array}$ & $\begin{array}{l}\text { Intestinal cancer } \\
\text { Other hazards* }\end{array}$ & $>23$ & $\begin{array}{c}60 \mathrm{mg} \\
\text { (RDA USA, Canada, etc) }\end{array}$ \\
\hline Ischemic heart disease & $>50$ & $100 \sim 150 \mathrm{mg}$ \\
\hline Intestinal cancer & $>25$ & $30 \sim 50$ IU \\
\end{tabular}

* 労働能力, 歯周コラーゲン, 精子凝集に関するもの。

つとされ, 生理効果についても遊離型とエステル型については同効力で分子量だけの換算で生理効果が示され てきた（米国の栄養所要量）。しかし，遊離型がエステル型に比べ，かなり生理効果が少ないとするデータは, 1977年に Leth and S $\phi$ ndergaad により発表されているが ${ }^{44}$, 最近, Weiser らは胎仔吸収試験, 筋ジストロフィー 試験 (ピルビン酸キナーゼ測定), 肝貯蔵試験で, 少量の RRR- $\alpha-\mathrm{Toc}(\mathrm{d}-\alpha-\mathrm{Toc})$, all-rac- $\alpha-\mathrm{Toc}$ (dl- $\alpha-\mathrm{Toc})$ を遊離型および酢酸エステルで投与し, 生理効果を検討している25)。その結果, 欠乏からの回復といった少量 の投与試験では, 酢酸エステルの生理効果が遊離型に比べ, はるかに大きいことを見出し, 全体として酢酸エ ステル1.00とすると, 遊離型0.7位のデータを, RRR- $\alpha$-Toc と all-rac- $\alpha$-Toc について得ている。一方, ヒ トの場合, 大量に投与すると, 遊離型のほうが血清のビタミン $\mathrm{E}$ 值の上昇効果が高いとするデータもある26)。 このことは, ビタミン E においては, 栄養所要量程度の少量摂取の場合, 遊離型よりはエステル型のほうが 消化・吸収時の分解が小さく, 効果が大きくなることを意味し, 大量投与の場合はエステル型よりは遊離型の ほうが吸収率が若干上昇するため，血清中の $\alpha$-トコフェロール値の上昇をもたらすものといえよう。

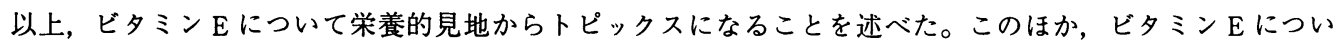
ては年間数100の論文が公表されているほか, 臨床的な応用例の論文も多い。これらについては割愛した。以 下の成書を参考にされたい。

(1) ビタミン E一基礎と臨床一 (五十嵐脩編), 1985, 医歯薬出版, 東京

(2) Vitamin E-comprehensive treatise (Machlin, L. ed.), 1980, Dekker, N. Y.

(3) ビタミン学 ( I ) (日本ビタミン学会編), ビタミン E, pp. 177 235, 1980, 東京化学同人, 東京

(4) Biology of vitamin E (Chiba Foundation symp. 101), 1983, Pitman, London

(5) Clinical and nutritional aspects of vitamin E (Hayaishi, O. and Mino, M. eds.), 1987, Elsevier, Amsterdam

文献

1）五十嵐脩：ビタミン E/五十嵐脩編, p.537（1985）医歯薬出版 
2) Burton, G. W. and Ingold, K. U. : J. Am. Chem. Soc., 103, 6472 (1981)

3) Niki, E., Saito, T., Kawakami, A. et al. : J. Biol. Chem., 259, 4177 (1984)

4) Packer, J. E., Slater, T. F. and Wilson, R. L. : Nature, 278, 737 (1979)

5) Simic, M. G. : Autoxidation - Food and Biological System /Simic, M. G. and Karel, M. eds., p. 17 (1980) Plenum Press, N. Y.

6）小沢順子, 他：栄養と食糧, 33, 393 (1980)

7) Lehman, J. and Slover, H. T. : Lipids, 11, 853 (1976)

8）早石 修：虚血と細胞障害/早石 修, 八木国夫，五島雄一郎編，p.16（1980）医歯薬出版

9) Matsushita, S. et al : Tocopherol, oxygen and biomembranes, p.23 (1978) Elsevier, Amsterdam

10）木村修一：栄養と食糧，34，241（1982）

11）五十嵐脩，毛利佳世：ビタミン，58，1（1984）

12) Traber, M. G. and Kayden, H. J. : Am. J. Clin. Nutr., 40, 747 (1984)

13） Horwitt, M.K.：栄養と食糧，35，253（1982）

14）鄭 承鏞, 小畠義樹, 黒田圭一, 西出英一, 印南 敏：栄養学雑誌, 42, 31 (1984)

15) Mouri, K., Ikesu, H., Esaka, T. and Igarashi, O. : J. Nutr. Sci. Vitaminol., 30, 307 (1984)

16）佐野優子, 五十嵐修：昭和 62 年度日本栄養・食糧学会講演要旨, p. 64 , 坂戸

17）毛利佳世, 江坂知美, 五十嵐脩：日本栄養·食糧学会誌, 37, 441 (1984)

18) Mouri, K., Hayafune, Y., Igarashi, O. : J. Nutr. Sci. Vitaminol., 32, 147 (1986)

19) Niki, E., Saito, T., Kawakami, A. et al. : J. Biol. Chem., 259, 4177 (1984)

20) Yamauchi, R., Kato, K. and Ueno, Y. : Agric. Biol. Chem., 25, 2855 2861 (1981)

21) Chen, L. H. : Am. J. Clin. Nutr., 34, 1036 (1981)

22) Igarashi, O., Mouri, K. and Chen, L. : Clinical and Nutritional aspects of vitamin E/Hayaishi, O. and Mino, M. eds., p. 63 (1987) Elsevier, Amsterdam

23) Gey, K. F., Brubacker, G. B. and Stähelin, H. B. : Am. J. Clin. Nutr., 45, 1368 (1987)

24) Leth, T. and Sфndergaad, H. : J. Nutr., 107, 2236 (1977)

25) Weiser, H., Vecchi, M. and Schlachter, M. : Intnat. J. Vit. Nutr. Sci., 56, 45 (1986)

26) Week, E. F., Sevigne, F. J. and Ellis, M. E. : J. Nutr., 46, 353 (1952) 